\title{
Assessing Sport and Recreation Programmes’ Service Quality at Hotels and Resorts: Towards Enhancing Customer Participation
}

\author{
Lim Khong Chiu \\ Universiti Utara Malaysia, Kedah, Malaysia \\ Radzliyana Binti Radzuwan \\ Universiti Institut Teknologi MARA, Perlis, Malaysia \\ Cheah Swee Ting \\ Universiti Utara Malaysia, Kedah, Malaysia
}

\begin{abstract}
Many issues and challenges are faced by the managers and professionals in managing sport and recreation programmes today. Although many previous researches on service quality provided by the organizations had been explored, very few studies pertaining to service quality in sport and recreation programmes in local hotels and resorts have been emphasized. This study aims to assess customers' perceptions of service quality in sport and recreation programmes and to determine the differences between customers' perceptions of service quality in terms of their gender and nationality. A total of 450 respondents from the hotels and resorts located in coastal areas of the northern Peninsular Malaysia participated in the survey. They were asked to respond to a series of the adapted service quality (SERVQUAL) items to measure five dimensions of service quality including tangibles, assurance, responsiveness, reliability, and empathy. Results from this study revealed that the customers' perceptions of the overall services in sport and recreation programmes provided by the hotels and resorts were satisfactory. It was also indicated that there was no significant difference between male and female customers' perceptions of service quality in sport and recreation programmes. Conversely, the results revealed that there was a significant difference between local and foreign customers' perceptions of sport and recreation services provided. These findings had implications on sport and recreation programmes in relation to designing effective management and marketing strategies at hotels and resorts.
\end{abstract}

Keywords: customers’ perceptions, service quality, sport and recreation programmes, tourism industry

\section{Introduction}

Customers' satisfaction and service quality are closely related and crucial to the organization managers and marketers to design effective management and marketing strategies. A considerable body of research in the

Lim Khong Chiu, associate professor, School of Tourism, Hospitality, and Environmental Management, Universiti Utara Malaysia.Email: lkc@uum.edu.my.

Radzliyana Binti Radzuwan, senior lecturer, Sport Science and Recreation Unit, Universiti Institut Teknologi MARA.

Cheah Swee Ting, assistant researcher, School of Tourism, Hospitality, and Environmental Management, Universiti Utara Malaysia. 
broader management and marketing literature has focused on the nature of satisfaction and its relationship to service quality and the future intentions of customers (Brady \& Robertson, 2001; Greenwell, Fink, \& Pastore, 2002; Kang, Okamoto, \& Donovan, 2004). However, there has been limited research in this field specific to sport and recreation context in Malaysia. A clearer understanding of how to produce satisfied customers in a sport or recreation setting will help managers to better predict the return of customers. Several studies support the notion that satisfaction is a consequence of service quality (Brady \& Robertson, 2001; McDougall \& Levesque, 1994; 2000; Zeithaml, 1988), and this appears consistent across service perspective (Murray \& Howat, 2002). As such, the organizations and firms quite often use customer satisfaction and perceived service quality as a measure of product or service performance (Anderson \& Sullivan, 1993) as well as a marketing strategy for the service industries (Zeithaml, Parasuraman, \& Berry, 1996).

In the sport and leisure literature, service quality has been conceptualized in different ways. Thus, differences exist relative to how perceptions of service quality are measured (U. Lehtinen \& J. R. Lehtinen, 1991; Zeithaml, Parasuraman, \& Berry, 1990). For example, since its introduction, the service quality (SERVQUAL) (Zeithaml, Parasuraman, \& Berry, 1988) scale has either been directly utilized by many researchers or modified to tailor more specifically to the services of the fitness and recreational sport industry (e.g., Crompton, Mackay, \& Fasenmaier, 1991; Howat, Absher, Crilley, \& Milne, 1996; Mackay \& Crompton, 1988; Wright, Duray, \& Goodale, 1992). In addition, several researchers have attempted to develop sound factor structures of service quality for different segments of the sport industry (Howat et al., 1996; D. Kim \& S. Y. Kim, 1995). However, empirical examinations of the sport, fitness, and leisure literature offer little to support commonly agreed upon dimensions of service quality to date.

According to U. Lehtinen and J. R. Lehtinen (1991), in the context of sport and recreation programmes, the targets of quality evaluation include: (1) the core service; (2) the physical context including the facilities and equipment in which service is provided; and (3) the interpersonal interaction in the performance of the service. In fact, a unique dimension identified by U. Lehtinen and J. R. Lehtinen (1991) refers to the quality of client participation in the production of the service, as client participation is fundamental to the production of most services in sport and recreation, and clients' perceptions of the quality of their own involvement are critical for continued participation in that activity. Perhaps, the increasing interest in service quality has motivated many scholars to research the topic. However, in the field of sport and recreation management, despite many related studies are conducted at the activities or programmes, very few studies have been published regarding service quality (Chelladurai \& Chang, 2000; Yong \& Pastore, 2004). Few research studies in this regard have focused on identifying dimensions of quality-specific services (e.g., fitness service, leisure service, and recreation service). For example, Chelladurai, Scott, and Hayward-Farmer (1987) identified five dimensions of fitness services as measured by their Scale of Attributes of Fitness Services (SAFS). These dimensions are primary-professional, primary-consumer, primary-facilitating goods, and secondary goods and services. The first dimension reflects the core service, while the rest dimensions reflect the context which encompasses the quality of the facilities, their location, the equipment, and the tools used in the production of the service as well as the amenities provided to the clients (Chelladurai \& Chang, 2000).

On the other hand, based on literature review and focus group results, D. Kim and S. Y. Kim (1995) generated 45 items to assess service quality in sport in South Korea. They measured the desirability of the items as well as the delivery of the service indicated by the items (i.e., perceived performance). They derived an 
11-factor 33-item measurement titled Quality Excellence of Sport Centres (QUESC). The 11 dimensions were labeled ambience, employee attitude, reliability, information, programming, personal consideration, privileges, price, ease of mind, stimulation, and convenience. In other related studies, Yi and Lee (2001) developed Korean Standard-Service Quality Index (KS-SQI) measurement, which balances the process dimensions and the outcome dimensions of service quality. They indicated that customer awareness of service quality is composed of process quality dimensions and outcome quality dimensions. They divided each of these categories into four categories. Process quality was divided into accessibility, physical aspects, credibility, and receptiveness. Outcome quality was divided into creativeness, primary needs fulfillment, unexpected benefits, and contact performance.

In addition, Howat et al. (1996) developed the Centre for Environmental and Recreation Management-Customer Service Quality (CERM-CSQ) scale to measure four dimensions of service in sport and leisure centres. These dimensions are: (1) core service, including programme information, range of activities, facilities comfort, value for money, and quality equipment; (2) staff quality, including staff responsiveness, staff knowledge, and officials; (3) general facility, including safe parking and facility cleanliness; and (4) secondary service, including food and drink and child minding. However, in an earlier research, Chelladurai (1992) classified sport services into two broader sets: (1) participant services; and (2) spectator services. According to him, an understanding of the sport services and their classification would facilitate the discussion of quality in those services.

Meanwhile, McDougall, Sutton, and Milne (1995) and Shilbury (1994) have also discussed service quality in professional sport. In fact, McDougall et al. (1995) developed the team quality (TEAMQUAL) scale consisting of 39 items to measure five dimensions of service quality in professional team sports. These five dimensions are patterned after those identified in SERVQUAL (Parasuraman, Zeithaml, \& Berry, 1994). As such, the dimensions are based on the idea that quality judgment is based on the gap between customers' expectations and perceptions. With the introduction of SERVQUAL, the scale has been widely used in various service industries (Yong \& Pastore, 2004). While Cronin and Taylor (1992) acknowledged that the 22 SERVQUAL measurement items are appropriate, they argued that a model measuring perceptions of service delivery results is more appropriate than the gap's model, which relies on a difference between expectation and experience. Thus, using the same items as SERVQUAL but referring only to the effect, service quality, they proposed service perception (SERVPERF).

Furthermore, due to the difficulty in understanding consumers' expectations (with there being no clear set of expectations for each service setting), it is often argued that "perceptions only" as a measure of satisfaction (one that excludes expectations) is more useful (Allen, O’Toole, Harris, \& McDonnell, 2008). In addition, according to Lewis and Booms (1983), perceived service quality represents a more firm positive or negative attitude towards various service-related attributes. Therefore, from the practitioners' point of view, the explication of perceived service quality construct might appeal for more research interest, because it can be proven to be a useful management tool (Papadimitriou \& Karteroliotis, 2000). Service quality is obviously very important for the long-term profitability of any organization (Zeithaml et al., 1996). Knowledge gained from such behavioral research will eventually help practitioners as well as researchers. It is vital for organizations' marketers and managers to know what motivates customers to participate in sport and recreation programmes as well as to fulfill their needs and wants. 


\section{Sport and Recreation Programmes in Tourism Industry}

Sport and recreation programmes as part of business in tourism and hospitality are big, profitable, and growing, with most of the clients are sports' enthusiasts. Hotels and travel agents are always on the lookout for new markets as a way of broadening their business. Furthermore, fitness- and health-conscious baby boomers among the tourists who travel as part of their leisure or business have made a significant impact on all forms of travel and entertainment. People do not simply sit around on the beach on holiday any more, but increasingly engage in a wide range of recreational and sporting activities. This interest in recreation and sport has also been fuelled by the increasing emphasis of individuals on their health, well-being, and weight control, a movement which continues to grow at the beginning of the 21st century. Thus, recreational sport activities are acknowledged as important and potentially health-enhancing activities for which tourism can be the catalyst (Glyptis, 1991), and hence, health care and providing services for physical activities have become important parts of the tourism industry. Thus, the effective and efficient management of the sport and recreation programmes in the service sector (e.g., hotels and resorts) is crucial so that both the consumers and the organizations can prosper in the long term to bring positive benefits to all.

In the 21st century, the fitness- and health-conscious baby boomers, whose travel is part of their business, have made a significant impact on all forms of travel and entertainment. Airlines, car rental, and other travel services are yielding to the demands of the health- and fitness-conscious consumers. No smoking venue is now the mode. Vendors no longer consider heart-healthy food menus novel and bothersome. Hotels designed to market the business travel are expanding to provide fitness facilities (Grantham, Patton, York, \& Winick, 1998). Historically, the 4- or 5-star hotels provided only a pool to accommodate family recreation needs. Now, hotels with fully equipped exercise facilities are becoming commonplace. The upscale hotels with an affluent guest market and convention trade frequently developed full-scale spa services to supplement their fitness facilities. Some are even attempting to become destination resorts where they provide golf, tennis, and spa services. Hotels without a direct access to such services as golf and tennis frequently develop joint ventures with clubs where guests may use their golf and tennis facilities on a preferred or reduced cost basis. Most hotel-based facilities combine a membership programme comprising local residents and nearby business professionals to complement the hotel resort clientele. In short, the traveling publics are expecting no compromise to their lifestyles when away from home on business or for pleasure. This trend will probably continue for the foreseeable future.

However, there are many issues and challenges facing the managers and professionals in managing sport and recreation programmes today. Although many previous researches on service quality provided by the organizations had been explored, very few studies pertaining to service quality in sport and recreation programmes in local hotels and resorts have been emphasized. In managing sport and recreation programmes in hotels and resorts, service quality should be defined by the customer's overall impression of the service performance, service delivery systems, and overall consumption experiences (Yong \& Pastore, 2004). Service quality is recognized as one of the most important areas in the field of service management and marketing. Hence, in the field of service management and marketing, the related literature indicates that providing quality service is not only the most important factor for customer satisfaction (Parasuraman et al., 1994; Gronroos, 1990), but it is also the principal criterion that measures the competitiveness of a service organization (Lengnick-Hall, 1996). Thus, managers are now focusing on the process of service production and consumption, 
as it governs consumer behavior in the service industry where services are produced and consumed simultaneously. In other words, the success of managing sport and recreation programmes may depend on the degree to which the hotels and resorts can satisfy their customers with quality services.

Nevertheless, the challenge for sport and recreation programmers in tourism industry is to provide leisure experiences that improve the quality of life of their sport and recreation consumers and to contribute to the development of their emotional, physical, social, and cognitive lives. At the same time, the sport and recreation programmers need to be aware of special societal needs related to race and ethnicity, sex and gender roles, disability, age, and related factors, with an emphasis on recreation's important role as a health-related form of experience and social service (Cordes \& Ibrahim, 2003; Torkildsen, 2000). In the context of this study, sport and recreation programmes refer to the full range of organized and structured leisure experiences offered by hotels and resorts, as well as the unstructured or unsupervised use of play areas, sports facilities, and other indoor or outdoor recreation settings. It may also refer to activities carried on throughout the year, during a specific season, for a limited term, or on a single occasion. This study aims to examine customers' perceptions of service quality in sport and recreation programmes at hotels and resorts in coastal areas of the northern Peninsular Malaysia. As such, the findings will create the challenge of providing and maintaining high levels of service, awareness of customers' expectations, and improvement in sport and recreation services and products in the hotels and resorts.

\section{Objectives of the Study}

Specifically, this study was designed:

(1) To develop a demographic profile of customers who participate in the sport and recreation activities organized by the hotels and resorts management;

(2) To assess customers' perceptions of service quality in the sport and recreation programmes;

(3) To determine the differences between customers' perceptions of service quality in sport and recreation programmes in terms of their gender and nationality.

\section{Method}

A quantitative approach by using self-completion questionnaire of customers' perceptions was carried out at the selected hotels and resorts located at coastal areas of the northern Peninsular Malaysia.

\section{Sample}

A total of 450 respondents from 4- and 5-star hotels and resorts participated in the survey. A convenience sampling method was applied to select the sample from 10 randomly selected 4- and 5-star hotels and resorts located on the islands of Langkawi, Penang, and Pangkor. Convenience sampling refers to the collection of information from members of the population who are conveniently available to provide it. It is the best way of getting some basic information quickly and efficiently (Sekaran, 2003).

\section{Instrumentation and Procedures}

The questionnaire was developed as a respondent-completed survey consisting of two sections. In the first section, the questionnaire was designed to gather respondents' socio-demographic characteristics (age, gender, level of education, occupational status, income level, marital status, ethnic group, and residence). In the second section, the measurement items have been adapted from SERVQUAL (Zeithaml et al., 1988; 1990) and utilized to measure customers' perceptions of service quality in sport and recreation programmes. SERVQUAL is an 
empirically-derived method that is widely used by a service-based organization to improve the service industry by understanding the target customers' perceived services needs and measuring their perceptions of service quality for the services offered (Murray \& Howat, 2002). In this study, the survey instrument took the form of a direct disconfirmation 22-item self-completion questionnaire. For each item, respondents were asked to rate their perceptions of service quality pertaining to sport and recreation programmes on a 4-point scale, ranging from strongly disagree (1) to strongly agree (4). Scale items were grouped according to five key dimensions of SERVQUAL including: assurance, empathy, reliability, responsiveness, and tangible elements of the customers' experience. The five dimensions of SERVQUAL are defined as follows:

(1) Tangibles: the appearance of physical facilities, equipment, personnel, and communication materials;

(2) Reliability: the ability to perform the promised service dependably and accurately;

(3) Responsiveness: the willingness to help customers and provide prompt service;

(4) Assurance: the knowledge and courtesy of employees and their ability to convey trust and confidence;

(5) Empathy: the provision of caring, individualized attention provided to its customers by the organization (Parasuraman, Zeithaml, \& Berry, 1988; Parasuraman et al., 1994).

The psychometric properties of the scales have been tested and the results have demonstrated good internal consistency and construct reliability. The results showed that the alpha coefficients for all five dimensions ranged from 0.83 to 0.87 , well above the minimum value of 0.6 as an indication of reliability (Hair, Anderson, Tatham, \& Black, 1998). This is consistent with Greenwell et al. (2002), Parasuraman et al. (1988), and Yong and Pastore (2004) who also measured service quality by utilizing the SERVQUAL items.

A total of 450 respondents who participated in the survey were asked to respond to the questionnaire provided. Permission to collect data with customers was received from selected hotels and resorts' administrators. Questionnaires were administered by three trained enumerators for the purpose of data collection. Respondents who agree to participate were asked to fill out the questionnaire and return it to the enumerators. Respondents were informed concerning the purpose of the study, general instructions were provided, help was offered when needed, and responses were anonymous.

\section{Results and Discussion}

\section{Demographic Profile of Respondents}

Completed questionnaires from 447 respondents were included in the analysis. As shown in Table 1, the demographic profile of respondents was composed of 50.9\% (224) males and $49.1 \%$ (216) females. With respect to their marital status, 61\% (271) were married and 39\% (173) were single. The age range of the sample was from 18 years old to 65 years old and more, with the majority of them being 26-35 years old (36.3\%, 162), 18-25 years old $(25.1 \%, 112)$, and 46-55 years old (20.2\%, 90). Among respondents, $39.9 \%$ (177) worked in the management and professional fields, $17.6 \%$ (78) were self-employed, and $17.3 \%$ (77) of the respondents were still studying. Of the total respondents, 68.2\% (304) were local Malaysians and 31.8\% (142) were foreigners. In terms of education level, the majority of the respondents had obtained their bachelor degrees (42\%, 183), and 30\% (131) with diploma or certificate level. Meanwhile, the majority of the respondents were Malay $(37.5 \%, 167)$, followed by Chinese $(23.6 \%, 105)$, Indian $(10.8 \%, 48)$, and other racial groups $(28.1 \%, 125)$. 
Table 1

Respondents' Demographics Characteristics $(n=447)$

\begin{tabular}{|c|c|c|}
\hline Demographic characteristic & Frequency & Percentage (\%) \\
\hline \multicolumn{3}{|l|}{ Gender $(n=440)$} \\
\hline Male & 224 & 50.9 \\
\hline Female & 216 & 49.1 \\
\hline \multicolumn{3}{|l|}{ Age $(n=446)$} \\
\hline $18-25$ & 112 & 25.1 \\
\hline $26-35$ & 162 & 36.3 \\
\hline $36-45$ & 52 & 11.7 \\
\hline $46-55$ & 90 & 20.2 \\
\hline $56-65$ & 24 & 5.4 \\
\hline$>65$ & 6 & 1.3 \\
\hline \multicolumn{3}{|l|}{ Education level $(n=436)$} \\
\hline Up to secondary level & 77 & 17.7 \\
\hline Diploma/certificate level & 131 & 30 \\
\hline First degree level & 183 & 42 \\
\hline Tertiary degree level & 45 & 10.3 \\
\hline \multicolumn{3}{|l|}{ Occupation $(n=444)$} \\
\hline Student & 77 & 17.3 \\
\hline Self-employed & 78 & 17.6 \\
\hline Unemployed & 35 & 7.9 \\
\hline Professional \& management & 177 & 39.9 \\
\hline Retiree & 18 & 4.0 \\
\hline Business & 47 & 10.6 \\
\hline Others & 12 & 2.7 \\
\hline \multicolumn{3}{|l|}{ Marital status $(n=444)$} \\
\hline $\begin{array}{l}\text { Single } \\
\end{array}$ & 173 & 39 \\
\hline Married & 271 & 61 \\
\hline \multicolumn{3}{|l|}{ Ethnic group $(n=445)$} \\
\hline Malay & 167 & 37.5 \\
\hline Chinese & 105 & 23.6 \\
\hline Indian & 48 & 10.8 \\
\hline Others & 125 & 28.1 \\
\hline \multicolumn{3}{|l|}{ Nationality $(n=446)$} \\
\hline Local Malaysian & 304 & 68.2 \\
\hline Foreign (International) & 142 & 31.8 \\
\hline
\end{tabular}

\section{Perceptions of Service Quality}

An examination of the mean scores revealed that the customers' perceptions of the overall service quality provided by the hotels and resorts are satisfactory with a mean score of 2.967 from a maximum score of 4 . Means and standard deviations for each of the dimensions used in this analysis are presented in Table 2. The results for the five dimensions of service quality show similar patterns with the mean scores for tangibles ( $M=2.998)$, reliability $(M=2.966)$, responsiveness $(M=2.974)$, assurance $(M=2.989)$, and empathy ( $M=2.928$ ). These findings indicated that customers' perceptions of the service quality in sport and recreation programmes were moderately associated with customers' satisfaction pertaining to staff competence in carrying out the activities, performing the promised service, staff appearance, caring and courtesy of staff, and facilities 
and equipment provided. Thus, the results of this study suggest the need for further improvement in sport and recreation programmes' services provided by the management of the hotels and resorts.

Table 2

Means and Standard Deviation Distribution of Scores of Service Quality in Sport and Recreation Programmes

\begin{tabular}{llll}
\hline Dimension & $n$ & $M$ & S.D. \\
\hline Tangibles & 445 & 2.998 & 0.559 \\
Reliability & 442 & 2.966 & 0.582 \\
Responsiveness & 445 & 2.974 & 0.611 \\
Assurance & 444 & 2.989 & 0.620 \\
Empathy & 431 & 2.928 & 0.637 \\
Overall service quality & 431 & 2.967 & 0.542 \\
\hline
\end{tabular}

The results in Table 3 indicate that there is no significant difference between male and female customers' perceptions of overall service quality in sport and recreation programmes $(t=-0.643, p=0.521)$. Likewise, in a separate analysis on the five dimensions of service quality, the results also indicate that there is no significant difference between male and female customers' perceptions. Based on the mean scores for each dimension, the results show that the service quality in sport and recreation programmes provided by the hotels and resorts received a better rating from the female customers. Thus, the findings of this study give a clear indication that both male and female respondents' perceptions are found to be of no significant difference in evaluating sport and recreation services provided by the hotels and resorts.

Table 3

Comparison of Respondents'Perceptions Scores of Service Quality in Sport and Recreation Programmes in Terms of Gender

\begin{tabular}{|c|c|c|c|c|c|c|}
\hline Dimension & $n$ & $M$ & S.D. & $d f$ & $t$ & $p$ \\
\hline \multicolumn{7}{|l|}{ Tangibles } \\
\hline Male & 224 & 2.957 & 0.597 & 436 & -1.16 & 0.247 \\
\hline Female & 214 & 3.019 & 0.518 & & & \\
\hline \multicolumn{7}{|l|}{ Reliability } \\
\hline Male & 222 & 2.941 & 0.621 & 434 & -0.84 & 0.415 \\
\hline Female & 214 & 2.987 & 0.541 & & & \\
\hline \multicolumn{7}{|c|}{ Responsiveness } \\
\hline Male & 223 & 2.951 & 0.643 & 436 & -0.783 & 0.434 \\
\hline Female & 215 & 2.997 & 0.579 & & & \\
\hline \multicolumn{7}{|l|}{ Assurance } \\
\hline Male & 222 & 2.990 & 0.656 & 435 & 0.025 & 0.980 \\
\hline Female & 215 & 2.988 & 0.594 & & & \\
\hline \multicolumn{7}{|l|}{ Empathy } \\
\hline Male & 222 & 2.926 & 0.685 & 433 & -0.026 & 0.980 \\
\hline Female & 213 & 2.928 & 0.586 & & & \\
\hline \multicolumn{7}{|c|}{ Overall service quality } \\
\hline Male & 217 & 2.949 & 0.582 & 423 & -0.643 & 0.521 \\
\hline Female & 208 & 2.982 & 0.497 & & & \\
\hline
\end{tabular}

Note. Significant value $(p<0.05)$. 
However, on the other hand, the results as shown in Table 4 indicate that there is a significant difference between local and foreign customers' perceptions of the overall service quality of the services provided in sport and recreation programmes $(t=-5.634, p=0.001)$. Likewise, the results also reveal that there is a significant difference between local and foreign customers' perceptions of the five dimensions of service quality (tangibles: $t=-5.560, p=0.001$; reliability: $t=-5.156, p=0.001$; responsiveness: $t=-5.170, p=0.001$; assurance: $t=-5.275, p=0.001$; and empathy: $t=-5.336, p=0.001$ ). Based on mean scores of the data, the results showed that foreign customers perceived a better service quality towards sport and recreation programmes provided compared to local customers. Thus, the findings could imply that the foreign customers are generally more satisfied when compared to local customers in terms of sport and recreation programmes' services at hotels and resorts. The findings seem to support the fact that cultural backgrounds do play an important role in influencing customers' perceptions of service quality, in terms of their evaluation on sport and recreation programmes. Meanwhile, value might be a mediator in perceptions of service quality (McDougall \& Levesque, 2000). Value may be viewed as the evaluation of what is received compared to what is given in a service encounter (Zeithaml, 1988). Thus, in forming overall perceptions of service, customers may use value to evaluate the service compared to alternatives available to them, which, in turn, influence satisfaction judgments and future intentions of customers (Cronin, Brady, \& Hult, 2000). Based on the findings, this study suggests that managers of the hotels and resorts need to develop some understanding of the needs and wants of the customers and their cultural differences, as well as their perceived value in sport and recreation participations in order to ensure that the provision of services is able to satisfy their customers.

Table 4

Comparison of Respondents' Perceptions Scores of Service Quality in Sport and Recreation Management in Terms of Nationality

\begin{tabular}{|c|c|c|c|c|c|c|}
\hline Dimension & $n$ & $M$ & S.D. & $d f$ & $t$ & $p$ \\
\hline \multicolumn{7}{|l|}{ Tangibles } \\
\hline Local & 303 & 2.892 & 0.566 & 442 & -5.560 & 0.001 \\
\hline Foreign & 141 & 3.199 & 0.484 & & & \\
\hline \multicolumn{7}{|l|}{ Reliability } \\
\hline Local & 301 & 2.871 & 0.589 & 440 & -5.156 & 0.001 \\
\hline Foreign & 141 & 3.179 & 0.512 & & & \\
\hline \multicolumn{7}{|c|}{ Responsiveness } \\
\hline Local & 303 & 2.875 & 0.642 & 442 & -5.170 & 0.001 \\
\hline Foreign & 141 & 3.188 & 0.525 & & & \\
\hline \multicolumn{7}{|l|}{ Assurance } \\
\hline Local & 302 & 2.887 & 0.639 & 441 & -5.275 & 0.001 \\
\hline Foreign & 141 & 3.211 & 0.517 & & & \\
\hline \multicolumn{7}{|l|}{ Empathy } \\
\hline Local & 300 & 2.821 & 0.655 & 439 & -5.336 & 0.001 \\
\hline Foreign & 141 & 3.157 & 0.530 & & & \\
\hline \multicolumn{7}{|c|}{ Overall service quality } \\
\hline Local & 294 & 2.869 & 0.551 & 429 & -5.634 & 0.001 \\
\hline Foreign & 137 & 3.174 & 0.456 & & & \\
\hline
\end{tabular}

Note. Significant value $(p<0.05)$. 


\section{Conclusions}

Understanding the customers is essential to creating successful sport and recreation programmes. Knowledge of customers' behaviors can assist the sport and recreation managers in successfully meeting their needs. Perhaps, the most important is the need for an organization to position itself towards service with a basic knowledge of customer behavior (C. R. Edginton, Hudson, Dieser, \& S. R. Edginton, 2004). In this regard, the focus of marketing activities in the hotels and resorts should take into consideration the customers' needs and wants in order to achieve its objective.

Generally speaking, the awareness of the importance of physical activity and fitness is at an all-time high in most of the societies today and will continue to increase in the future (Cordes \& Ibrahim, 2003; Edginton et al., 2004). Therefore, the managers will certainly have to stay abreast of the changes. If they are to deal with them, sport and recreation managers must be knowledgeable about the field of sport and recreation and be willing to assume leadership positions. Sport and recreation managers must understand these societal changes and plan their programmes and facilities accordingly. This will assist the organization in attracting and retaining customers.

The overall findings of the study have significant implications for leadership in recreational sport administration and management, particularly with respect to preparation of effective marketing and management strategies for the improvement of the daily operations of sport and recreation programmes in hotels and resorts. However, some limitations of this study need to be considered. The study was carried out in the hotels and resorts setting and was limited to customers of the hotels and resorts through non-random sampling technique for data collection. Thus, the results cannot be generalized to other settings. Therefore, it is recommended that an extended programme of research be conducted with consideration on sampling design and type of customers. This study also suggests modification measurement scales to be used to obtain qualitative data which may explain explicitly regarding customers' perceptions on service quality related to sport and recreation programmes. In spite of that, future research should also explore additional variables in terms of customers' satisfaction, perceived values, and future intentions of participating in sport and recreation programmes organized in relation to recreational sport industry, types of recreational sport activities, and other psychological variables such as goal achievement, self-efficacy, and other related attributes.

\section{References}

Allen, J., O’Toole, W., Harris, R., \& McDonnell, I. (2008). Festival and special event management (4th ed.). Milton, Queensland: John Wiley \& Sons Australia.

Anderson, E. W., \& Sullivan, M. W. (1993). The antecedents and consequences of customer satisfaction for firms. Marketing Science, 12(2), 125-143.

Brady, M. K., \& Robertson, C. J. (2001). Searching for a consensus on the antecedent role of service quality and satisfaction: An exploratory cross-national study. Journal of Business Research, 51(1), 53-60.

Chelladurai, P. (1992). A classification of sport and physical activity services: Implications for sport management. Journal of Sport Management, 6(1), 38-51.

Chelladurai, P., \& Chang, K. (2000). Targets and standards of quality in sport services. Sport Management Review, 3(1), 1-22.

Chelladurai, P., Scott, F. L., \& Haywood-Farmer, J. (1987). Dimensions of fitness services: Development of a model. Journal of Sport Management, 1(2), 159-172.

Cordes, K. A., \& Ibrahim, H. M. (2003). Application in recreation and leisure for today and the future (3rd ed.). New York, N.Y.: McGraw-Hill. 
Crompton, J. L., Mackay, K. J., \& Fesenmaier, D. R. (1991). Identifying dimensions of service quality in public recreation. Journal of Park and Recreation Administration, 9(3), 15-28.

Cronin, J. J., \& Taylor, S. A. (1992). Measuring service quality: A reexamination and extension. Journal of Marketing, 56(3), 55-68.

Cronin, J. J., Brady, M. K., \& Hult, G. (2000). Assessing the effects of quality, value, and customer satisfaction on consumer behavioral intentions in service environments. Journal of Retailing, 76(2), 193-218.

Edginton, C. R., Hudson, S. D., Dieser, R. B., \& Edginton, S. R. (2004). Leisure programming: Service-centered and benefits approach. New York, N.Y.: McGraw-Hill.

Glyptis, S. A. (1991). Sport and tourism. In C. Cooper (Ed.), Program in tourism, recreation, and hospitality management (pp. 165-183). London: Belhaven press.

Grantham, W. C., Patton, R. W., York, T. D., \& Winick, M. L. (1998). Health fitness management: A comprehensive resource for managing and operating programmes and facilities. Champaign, I.L.: Human Kinetics.

Greenwell, T. C., Fink, J. S., \& Pastore, D. L. (2002). Assessing the influence of the physical sports facility on customer satisfaction within the context of the service experience. Sport Management Review, 5(2), 129-148.

Gronroos, C. (1990). Service management and marketing: Managing the moment of truth in service competition. Lexington, MASS: Lexington Books.

Hair, J. F., Anderson, R. E., Tatham, R. L., \& Black, W. C. (1998). Multivariate data analysis. New Jersey, N.J.: Prentice Hall.

Howat, G., Absher, J., Crilley, G., \& Milne, I. (1996). Measuring customer service quality in sports and leisure centres. Managing Leisure, 1(2), 77-89.

Kang, S. K., Okamoto, N., \& Donovan, H. A. (2004). Service quality and its effect on customer satisfaction and customer behavioral intentions: Hotel and ryokan guests in Japan. Asia Pacific Journal of Tourism Research, 9(2), 189-202.

Kim, D., \& Kim, S. Y. (1995). QUESC: An instrument for assessing the service quality of sport centres in Korea. Journal of Sport Management, 9(2), 208-220.

Lehtinen, U., \& Lehtinen, J. R. (1991). Two approaches to service quality dimensions. The Service Industries Journal, 11(3), 287-303.

Lengnick-Hall, C. A. (1996). Customer contributions to quality: A different view of the customer-oriented firm. Academy of Management Review, 21(3), 791-824.

Lewis, R., \& Booms, B. (1983). The marketing aspects of service quality. In L. Berry, G. Shostack, \& G. Upah (Eds.), Emerging perspectives on service marketing. Chicago: American Marketing Association.

Mackay, K. J., \& Crompton, J. L. (1988). A conceptual model of consumer evaluation of recreation service quality. Leisure Studies, 7(1), 41-49.

McDougall, G. H. G., \& Levesque, T. J. (2000). Customer satisfaction with services: Putting perceived value into the equation. Journal of Services Marketing, 14(5), 392-409.

McDougall, G. H. G., \& Levesque, T. J. (1994). A revised view of service quality dimensions: An empirical investigation. Journal of Professional Services Marketing, 11(1), 189-209.

McDougall, M. A., Sutton, W. A., \& Milne, G. R. (1995). TEAMQUAL: Measuring service quality in professional team sports. Sport Marketing Quarterly, 4(1), 9-15.

Murray, D., \& Howat, G. (2002). The relationships among service quality, value, satisfaction, and future intentions of customers at an Australian sports and leisure centre. Sport Management Review, 5(1), 25-43.

Papadimitriou, D. A., \& Karteroliotis, K. (2000). The service quality expectations in private sport and fitness centers: A reexamination of the factor structure. Sport Marketing Quarterly, 9(3), 157-164.

Parasuraman, A., Zeithaml, V. A., \& Berry, L. L. (1988). SERVQUAL: A multiple-item scale for measuring consumers' perceptions of service quality. Journal of Retailing, 64(1), 22-37.

Parasuraman, A., Zeithaml, V. A., \& Berry, L. L. (1994). Reassessment of expectations as a comparison standard in measuring service quality: Implications for further research. Journal of Marketing, 58(1), 111-124.

Sekaran, U. (2003). Research methods for business: A skill building approach. Singapore: John Wiley \& Sons.

Shilbury, D. (1994). Delivering quality service in professional sport. Sport Marketing Quarterly, 3(1), 29-35.

Torkildsen, G. (2000). Leisure and recreation management (4th ed.). London: E \& FN Spon.

Wright, B. A., Duray, N., \& Goodale, T. L. (1992). Assessing perceptions of recreation centre service quality: An application of recent advancements in service quality research. Journal of Park and Recreation Administration, 10(3), 33-47. 
Yi, Y. J., \& Lee, J. Y. (2001). A reexamination of the measurement and consequences of service quality. Korea Marketing Review, 16(1), 3-19.

Yong, J. K., \& Pastore, D. L. (2004). Current issues and conceptualizations of service quality in the recreation sport industry. Sport Marketing Quarterly, 13(3), 158-166.

Zeithaml, V. A. (1988). Customer perceptions of price, quality, and value: A means-end model and synthesis of evidence. Journal of Marketing, 52(3), 2-22.

Zeithaml, V. A., Parasuraman, A., \& Berry, L. L. (1988). Communication and control processes in the delivery of service quality. Journal of Marketing, 52, 35-48.

Zeithaml, V. A., Parasuraman, A., \& Berry, L. L. (1990). Delivering quality service: Balancing customer perceptions and expectations. New York, N.Y.: The Free Press.

Zeithaml, V. A., Parasuraman, A., \& Berry, L. L. (1996). The behavioural consequences of service quality. Journal of Marketing, 60(2), 31-46. 